\title{
DEVELOPMENT AND DIVERSIFICATION OF SERVICES - AN APPROACH AT TOURISM SERVICES LEVEL IN ROMANIA
}

\author{
Andreea Daniela Moraru ${ }^{1}$
}

\begin{abstract}
The paper aims at arguing the importance of development and diversification at services level, and especially at tourism services level. To this end, the paper approaches the two concepts of development and diversification and briefly presents the circumstances claiming for development and diversification of services in tourism; it also reviews the benefits brought by the development and diversification given the characteristic features of the industry and presents the results of a research conducted among the tourists visiting the Romanian seaside. The conclusions of the research strengthen the argument for due importance that should be given to the development and diversification of services, since tourists' assessment of development and diversification level impacts the frequency of visit and their intention to revisit the destination during the next three years.
\end{abstract}

Key words: tourism services, international context, development, diversification, tourism dynamics

JEL Code: M31, L83, C12

\section{Introduction}

As ensemble of activities focused on satisfying tourists' needs during their stay, tourism services perform the role of capitalizing the tourist potential of a destination, becoming a catalyst for tourism development.

Bearing in mind the ampleness and dynamics of tourism as a phenomenon, a continuous process of development and diversification of tourism services in view of satisfying the consumer, can be observed.

The development and diversification of tourism services are argued and advocated by numerous specialists studying modern tourism, being considered as key elements for potential valorisation. The necessity to develop and diversify tourism services is obvious also in Romania where the extremely valuable tourism potential must be accompanied by adequate tourism services.

Sustaining this statement, the paper presents some of the results obtained following a research conducted among tourists visiting the Romanian seaside, which was aimed at getting knowledge of their opinion regarding services offered, of their assessment of services diversification level and whether this assessment impacts their intention to revisit the destination.

\section{Development and diversification concepts}

Considering the definition of the concept of development results that development regarded as activity focused on the improvement of existing products, may include various decisions such as: maintaining the products of the current product range, modernizing existing products or introducing new products.

Modernizing the product refers to its updating function of market demands, the process resulting in the emergence of a more or less modernized product or even in the emergence of a completely new product.

\footnotetext{
${ }^{1}$ Ovidius University of Constanța, Faculty of Economic Sciences, Romania, e-mail: andreea_aad@yahoo.com
} 
Applied at services level, given their intangibility, it may be easier compared to tangible products, to create different versions of an existing service, which may mean minor changes or true innovations.

The motivations sustaining the decision to create new services may be numerous, varying from the decline of a service and the necessity to replace it with a new one, to the intention to cover a market niche unexploited by competition or to aim for a risk reduction by enlarging the range of services provided.

Moreover, services must be modified, developed and updated continuously, in view of maintaining their market position, this process of constant services development being expected by the modern, informed consumers (Clarke, 2000).

Circumstances claiming the creation of a new service may be summarized as follows (Palmer, 1998):

- When a service has reached the maturity phase of its life cycle and is heading for the decline, new services may be sought in order to maintain the sales level;

- New services may be developed as a way of maximizing capacity use;

- New services may balance the organization's existing portfolio, reducing the risk of depending only on a few services;

- An organization may be forced to introduce new services in order to keep the clients and obtain their loyalty;

- When an opportunity arises for an organization to satisfy clients' needs with a new service, following a competitor exiting the market.

New services may refer to existing services, services that have been superficially changed, they may refer to existing services which have been substantially improved, or apparently new services that are currently available in the market, but are new for a certain organization that decides to adopt them, or may refer to completely new services, that is new services for new markets.

Diversification impacts the organization and also the economy in general and may be approached at micro and macro level, taking forms such as: diversification of production (offer), of consumption (demand), market diversification, diversification of terms and means of payment, of distribution and distribution channels, diversification of communication means etc.

The macroeconomic level diversification refers to the enlargement of national economies structures by development of new branches, sectors and domains of activity, and at microeconomic level it refers to the extension of product ranges of a company, by assimilation of new products.

Considering the technological and marketing links between new and previous products three forms of diversification at microeconomic level may be observed (Florescu et al, 2003):

- Concentric diversification - the new products are addressed to new consumer groups, valorisation of existing competences and technologies is possible, due to the links between the new products and the old ones;

- Horizontal diversification - the new products have no technological connections to the existing ones, but are addressed to the same consumer groups, new competences and technologies being necessary, but the existing marketing competences may be valorised;

- Conglomerate diversification - the organization approaches new domains with no connection to the existing technologies, products or markets, new competences and technologies being called for.

Organizations may also choose to pursue geographical diversification strategies, which involve approaching different geographic markets.

Although the literature has not reached consensus regarding the concept of diversification applied to services, it is acknowledged that it is related to innovation, it refers to offer differentiation by creating something novel. The innovation takes two forms: incremental innovation, responding to consumer demands for improvement of existing services and it is 
addressed to a well-known clientele and radical innovation which refers to the creation of completely new services (Bacher, 2005).

\section{Argument in favour of tourism services development and diversification}

Several arguments in favour of tourism services development and diversification may be brought to attention:

- The international context reshaping, characterized by economic instability and incertitude;

- Tourism sector dynamics;

- Fierce competition in tourism market;

- Transformations of consumer behaviour;

- Tourism services specific features offering multiple possibilities for new services creation;

- They may represent ways for tourism competitiveness growth.

In the field of services in general but especially in that of tourism services, due to their specific features the possibilities to create new services are numerous. First of all, the dynamics of tourism sector, the fierce competition and the changes in consumer behaviour recommend the constant development and diversification of tourism services in order to adapt to the evolving needs of tourists.

The most important element in the development and innovation of services refers to the production of services, where the consumers are also involved, as co-producers (Johnson, 2003). The producer - consumer interaction opens up multiple options for development and diversification of services provided, the consumers often becoming sources of new ideas.

Moreover, the development and diversification of tourism services may represent solutions for attenuation of tourism seasonality and economic efficiency growth. The seasonality brings the concentration of tourist flows in certain destinations at peak season, having as direct consequences the overload of equipment, the overcrowding or even the "suffocation" of destinations. The improvement or even the emergence of new services as well as the diversification of existing ones may offer solutions for season extension, with positive consequences both for tourists and service suppliers.

Development and diversification of tourism services are also considered ways to improve the quality of tourism services (Juran, 2004). The emergence of new market segments and the changes in consumer behaviour and preferences force the tourism organizations to redefine their target market and develop new products and services in order to be competitive. The present international climate, dominated by uncertainty accentuates this tendency to develop and diversify the offer in order to satisfy tourists' demands and preferences.

The diversification of tourism services includes also the so-called active holidays, as a consequence of the growing interest in active rest ways. This interest has emerged as a direct consequence of two major factors: the increase in free time and the stress felt by inhabitants of big, crowded cities.

Structural mutations and processes are obvious as far as the clientele is concerned, by the gradually shift of some tourists' interests from passive holidays to the active ones, and the offer of such holidays indeed represents a form of diversification, especially of the entertainment services.

Under these circumstances it is obvious that the development and diversification of tourism services represent viable solutions for obtaining superior economic results by tourism organizations and also for the evolution of tourism activity at both local and national level.

\section{Research regarding tourists' perception on the development and diversification of tourism services on the Romanian seaside}

A market research was conducted in order to identify correlations between the level of development and diversification of tourism services provided on the Romanian seaside and the 
tourists' socio-demographic characteristics and to establish whether the tourists are satisfied with the tourism services provided in the tourist towns and resorts of the seaside.

\section{Methodology}

A descriptive research of quantitative type aiming at assessing tourists' perception of tourism services provided on the Romanian seaside was conducted on a population formed of tourists who visited the Romanian seaside in the 2009 summer season.

A series of objectives and hypotheses were formulated; they referred to identifying tourists' motivations and opinions related to the seaside tourism services and testing the impact of development and diversification level of tourism services on tourist satisfaction, visit frequency and length of stay.

The survey was conducted between 15 of July and 31 of August 2009, in 16 tourist towns and resorts on the Romanian seaside, using as main research tool a questionnaire, compiled of 27 questions.

Having considered the complex character of the research proportional stratified sampling was used. The population was layered function of the holiday town/resort and their nationality, and from each layer sub-samples were extracted using simple random sampling.

The questionnaires were distributed in 16 tourist towns and resorts on the Romanian seaside, and after eliminating the ones being incomplete or under the suspicion of untrustworthiness 408 questionnaires were subject to analysis using SPSS (Statistical Data Analysis, version 17.0).

\section{Results}

Analyzing the results of the survey, several conclusions regarding most frequent tourist motivations, tourism services commercialization methods, frequency of visits, length of stay, preferred means of transport to and at destination, hospitality services and entertainment emerged.

These results may be summarized as follows:

- The majority of tourists $(72.8 \%)$ visit the seaside for recreational purposes; other visit motivations include balneal cures, business, and participation in events;

- $54.2 \%$ of the tourists used travel agents for booking the services, while $16.4 \%$ used the Internet;

- $58.8 \%$ of the Romanian tourists visit the seaside once a year and $10.3 \%$ visit the seaside twice a year, while most foreign tourists $(60.9 \%)$ are at their first visit;

- The length of stay is of 5.64 at sample level; 7.39 for foreign tourists and 5.54 days for the Romanian tourists;

- Most Romanian tourists used road transport means (62\%), while the foreigners used mostly air transportation (65.2\%);

- In order to assess tourists' opinion on different tourism services categories (hospitality, balneal, entertainment services) a semantic differential scale was preferred; the accommodation services received a 3.9 score indicating a favourable opinion of the sample; the balneal services are highly appreciated with a score of 4.07 ; food services receive a favourable opinion with a score of 3.75; the entertainment services received the least favourable opinion (3.25), with a lower score obtained from analysing the foreign tourists' opinion (2.73).

Several hypotheses were subsequently formulated, some of them directly related to the subject of services diversification.

The hypothesis referring to the influence of income, age and education on the tourism services diversification assessment was tested using the Chi-Square tests presented below (table no. 1, table no. 2 and table no.3). 
Table no.1

Testing the influence of income on diversification assessment

\begin{tabular}{|l|r|r|r|}
\hline \multicolumn{4}{|c|}{ Chi-Square Tests } \\
\hline & \multicolumn{1}{|c|}{ Value } & \multicolumn{1}{c|}{ df } & Asymp.Sig.(2-sided) \\
\hline Pearson Chi-Square & $36,260^{\mathrm{a}}$ & 28 &, 136 \\
\hline Likelihood Ratio & 38,091 & 28 &, 097 \\
\hline Linear-by-Linear Association &, 015 & 1 &, 903 \\
\hline N of Valid Cases & 408 & & \\
\hline
\end{tabular}

a. 22 cells $(55,0 \%)$ have expected count less than 5 . The minimum expected count is ,12.

The value of significance leads to the acceptance of the null hypothesis that is the income does not influence the opinion regarding the diversification of services.

Table no. 2

Testing the influence of age on diversification assessment

\begin{tabular}{|l|r|r|r|}
\hline \multicolumn{5}{|c|}{ Chi-Square Tests } \\
\hline & \multicolumn{1}{|c|}{ Value } & \multicolumn{1}{c|}{ df } & Asymp.Sig.(2-sided) \\
\hline Pearson Chi-Square & $29,219^{\mathrm{a}}$ & 20 &, 084 \\
\hline Likelihood Ratio & 29,279 & 20 &, 082 \\
\hline Linear-by-Linear Association & 1,492 & 1 &, 222 \\
\hline N of Valid Cases & 408 & & \\
\hline
\end{tabular}

a. 15 cells $(50,0 \%)$ have expected count less than 5 . The minimum expected count is, 13 .

The null hypothesis is also accepted in the case of age.

Table no.3

Testing the influence of education on diversification assessment

\begin{tabular}{|l|r|r|r|}
\hline \multicolumn{4}{|c|}{ Chi-Square Tests } \\
\hline & \multicolumn{1}{|c|}{ Value } & df & Asymp.Sig.(2-sided) \\
\hline Pearson Chi-Square & $49,358^{\mathrm{a}}$ & 24 &, 002 \\
\hline Likelihood Ratio & 44,203 & 24 &, 007 \\
\hline Linear-by-Linear Association & 2,134 & 1 &, 144 \\
\hline N of Valid Cases & 408 & & \\
\hline \multicolumn{1}{|c|}{ a. 21 cells (60,0\%) have expected count less than 5. The minimum expected count is ,01. }
\end{tabular}

In this case the null hypothesis is rejected, and we may conclude that tourists' level of education influences their assessment of tourism services diversification.

Another hypothesis was aimed at testing whether the opinion regarding the level of tourism services diversification influences the intention to revisit the destination in the next three years.

Reading the data of table no.4 one may observe that there is a significant correlation between the level of tourism services diversification and the intention to revisit the destination. 
Table no. 4

Correlation between the opinion regarding the tourism services diversification level and the intention to revisit the destination in the next three years

\begin{tabular}{|c|c|c|c|}
\hline & & $\begin{array}{l}\text { The opinion } \\
\text { regarding the } \\
\text { level of tourism } \\
\text { services } \\
\text { diversification } \\
\end{array}$ & $\begin{array}{l}\text { The intention to } \\
\text { revisit }\end{array}$ \\
\hline \multirow{3}{*}{$\begin{array}{l}\text { The opinion regarding the } \\
\text { level of tourism services } \\
\text { diversification }\end{array}$} & Pearson correlation & 1 & $446^{* * *}$ \\
\hline & Sig. (2-tailed) & &, 000 \\
\hline & $\mathrm{N}$ & 408 & 408 \\
\hline \multirow[t]{3}{*}{ The intention to revisit } & Pearson Correlation & $446^{* *}$ & 1 \\
\hline & Sig. (2-tailed) & ,000 & \\
\hline & $\mathrm{N}$ & 408 & 408 \\
\hline
\end{tabular}

**. Correlation is significant at the 0.01 level (2-tailed).

The results after using the lineal regression model are synthesised below (table no. 5).

Model Summary - regression

\begin{tabular}{|c|r|r|r|r|}
\hline Model & $\mathrm{R}$ & R & $\begin{array}{c}\text { Adjusted R } \\
\text { Square }\end{array}$ & $\begin{array}{c}\text { Std. Error of } \\
\text { the Estimate }\end{array}$ \\
\hline 1 &, $446^{\mathrm{a}}$ & \multicolumn{1}{|c|}{, 198} & \multicolumn{1}{c|}{, 197} &, 585 \\
\hline \multicolumn{4}{|c|}{ a. Predictors: (Constant), The opinion regarding the level of tourism services diversification } \\
\hline
\end{tabular}

The $\mathrm{R}$ value (0.0446) indicates a significant correlation between the two variables.

The $\mathrm{R}^{2}$ value indicated that $19.8 \%$ of tourists are influenced in their intention to revisit by the opinion regarding the level of tourism services diversification.

Subsequently, Chi-Square tests (table no. 6) were used to test the hypothesis regarding the influence of services diversification assessment on the intention to revisit the destination; the value of the Pearson Chi-Square test leads to the rejection of the null hypothesis, meaning that the diversification assessment indeed influences the intention to revisit the destination.

Table no.6

\section{Testing the influence of diversification assessment on the intention to} revisit the destination

\begin{tabular}{|l|r|r|r|}
\hline \multicolumn{5}{|c|}{ Chi-Square Tests } \\
\hline & \multicolumn{1}{|c|}{ Value } & df & Asymp.Sig.(2-sided) \\
\hline Pearson Chi-Square & $164,934^{\mathrm{a}}$ & 8 &, 000 \\
\hline Likelihood Ratio & 131,498 & 8 &, 000 \\
\hline Linear-by-Linear Association & 80,779 & 1 &, 000 \\
\hline N of Valid Cases & 408 & & \\
\hline
\end{tabular}

a. 6 cells $(40,0 \%)$ have expected count less than 5 . The minimum expected count is, 29 .

\section{Conclusions}

In the present economic conditions, it is clearer than ever that tourism services, given their proper place, may act as catalysts for destination development. Given the magnitude and dynamism of tourism a continuous process of tourism services development and diversification can easily be observed. 
In Romania tourism activity does not reach the level allowed by its valuable tourism potential, a strategic approach at tourism services level being called for. Development and diversification of tourism services as strategic approaches are recommended by services intrinsic characteristics and are sustained by a series of considerations related to international context reshaping, influenced by economic instability and uncertainty, the possibility to increase tourism competitiveness, sector dynamics, fierce competition on tourism market, and also consumer behaviour changes.

This statement is also supported by the conclusions of the research conducted and partially presented in this paper, especially the impact of diversification assessment on the frequency of visit and the intention to revisit the tourist destination.

In general, the opinion regarding seaside tourism services diversification level was satisfactory, but differences in this respect between the foreign and domestic tourists' appreciation were obvious, the foreigners being more demanding. Considering this conclusion the need for active measures oriented toward services is obvious, the fierce competition on tourism market leaving no other choice but to act in the direction of services improvement and diversification.

In our opinion, in the particular case of the Romanian tourism two main issues ought to be considered: the imperative necessity for differentiated tourism products aimed at satisfying the needs of different tourist segments, function of the motivational ensemble characterizing them, and the requirement to focus on additional and supplementary services which accompany hospitality and entertainment services, leading to increased consumer satisfaction.

The results of the survey reiterate the conclusion successful tourism destinations have reached already, that is the matter of tourism services should be reassessed, in the sense that modern tourists need and desire more than classic services offered by the hospitality industry. Every tourism organization must be aware of the quality imperative while it embraces a constructive approach focused on attention given to individual tourists and their demands, and the achievement of these objectives can only be possible by assuming the exigency for tourism services diversification.

\section{References}

1. Bacher T., 2005. Questioning the Diversification of Tourism Products: Two Examples of Achievement in the Mid-French Mountains - dissertation, Bournemouth University, Université de Savoie, pp. 34, available online at: http://www.du.se/PageFiles/5052/Bacher\%20Tanja\%20.pdf

2. Clarke G., 2000. Marketing a Service for Profit. A Practical Guide to Key Service Marketing Concepts, Kogan Page, London, pp. 80

3. Florescu C., Mâlcomete P., Pop N. Al. (coordinators), 2003. Dictionar de Marketing, Economica Publishing House, Bucharest, pp. 218-219

4. Johnson M. D., Gustafsson A., 2003. Competing in a Service Economy: How to Create a Competitive Advantage through Service Development and Innovation, John Wiley \& Sons, Inc., pp. 6

5. Juran J. M., Godfrey A. Blanton, 2004. Manualul calității Juran, $5^{\text {th }}$ Edition, Edited by The Romanian Society for Quality Assurance, SRAC Publishing House, Bucharest, pp. 30.2330.27

6. Palmer A., 1998. Principles of Services Marketing, $2^{\text {nd }}$ Edition, McGraw-Hill, London, pp. 49 